\title{
Water resources management: case study of Sharkia governorate, Egypt
}

\author{
Y. A. Mohamed • M. Rashad
}

Received: 31 January 2011/ Accepted: 11 January 2012/Published online: 26 January 2012

(C) The Author(s) 2012. This article is published with open access at Springerlink.com

\begin{abstract}
Ministry of water resources and irrigation in Egypt is currently implementing projects that expand new cultivated area, and accordingly the supplies of Nile River to the Nile Delta will be negatively affected. So, Enormous interest toward water resources management has been taken in the Egyptian water sector. Conveyance infrastructure and irrigation technology has been gradually improved to ensure efficient distribution and utilization of scarce water resources. The present study is focused on the optimum utilization of water resources in Sharkia governorate, Egypt. Operational and planning distribution model is implemented on the selected case study (Sharkia governorate) to develop appropriate water plan. The gross revenue of all crops is correlated to surface water discharge, ground water discharge, surface water salinity, and ground water salinity. In addition, the effect of varying both surface and groundwater quantities and qualities on the gross revenue has been investigated. Moreover, the effect of limiting rice production on the gross revenue is allocated.
\end{abstract}

Keywords Water resources management . Sharkia governorate - OPDM · Crop pattern .

Surface water $\cdot$ Groundwater

\section{Introduction}

Egypt is facing increasing water needs, demanded by a rapidly growing population, by increased urbanization, by

Y. A. Mohamed $(\bowtie) \cdot$ M. Rashad

Civil Engineering Department, College of Engineering,

Jazan University, Jazan, Saudi Arabia

e-mail: Yasser_eng1997@zu.edu.eg higher standards of living and by an agricultural policy that emphasis expanded production in order to feed the growing population. The main source of water in Egypt is surface water from the River Nile. The whole sources of water can be listed in Table 1 (Allam and Allam 2007). It is clear that Egypt's share of Nile water is fixed at 55.5 billion $\mathrm{m}^{3} /$ year. The groundwater, and to a lesser extent desalination and wastewater reuse, makes up the remainder (El-Sadek et al. 2008). Water resource management in Egypt is closely linked with numerous aspects of the national economy and social stability and at the same time has very direct effects on the health and livelihoods of many citizens. Two other management dimensions that deserve special mention are the regional hydro-politics in the Nile Basin, driven by ever stronger claims on the part of upstream countries for a higher share of the river runoff, and the increasing budgetary pressures on the water agencies, Luzi (2010). The need for effective and innovative water policies is evident, and the proposed strategies increasingly exceed the task of irrigation water distribution as traditionally performed by the Ministry of Water Resources and Irrigation (MWRI) in Egypt.

Demand management was strengthened through improved irrigation techniques, drainage water reuse, groundwater development, and restrictions on water release from Lake Nasser for non-consumptive uses (Elarabawy et al. 2000; MWRI and USAID 2002; MWRI and World Bank 2003). Water management strategies in the 1990s still focused mainly on water quantity issues (MWRI and World Bank 2003), even though water pollution problems had already reached alarming levels. Water scarcity is generally defined as the situation where there is insufficient water to satisfy normal requirements of the population. This means that water scarcity is a flexible term that depends on water use. The causes of water scarcity are varied. Some are natural, and others are as a result of human activity. 
Table 1 The available water sources in Egypt

\begin{tabular}{ll}
\hline Water resources (BCM/year) & Amount \\
Resource & 55.50 \\
Nile river & 5.50 \\
Groundwater (Delta and Valley) & 0.8 \\
Deep groundwater & \\
Drainage water reuse & 4.5 \\
Canals in the delta region & 5.0 \\
Nile river and Bahr Youssef & 3.0 \\
Illegal uses & 0.2 \\
Waste water reuse & 0.5 \\
Rainfall and flash floods & $(3)$ \\
Evaporation losses & 72.00 \\
Total &
\end{tabular}

Kenneth et al. (1996) investigated the vulnerability assessment of water resources in Egypt to climatic change in the Nile Basin. Dennis (1999) clarified the importance of the economic efficiency and irrigation water policy with an example from Egypt. The freshwater supply is essential, and desalination is a feasible option that can cover the wide gap between the available capacities and the accelerating demands, El-Sadek (2010). Cecilia et al. (2008) draw on the policy network perspective on governance to shed light on the strengths and weaknesses of watershed-based processes of collaboration and integration for water quality protection in agricultural areas. Bou-Zied and El-Fadel (2002) characterize water resources in several Middle Eastern countries and evaluate regional climate predictions for various scenarios using general circulation models. In the present study, the technique of Operational and Planning Distribution Model (OPDM) will be applied in Sharkia Governorate to correlate the gross revenue with the crop pattern of this zone. The command areas (78 command areas) in the Sharkia governorate are implemented into the OPDM model and also crop pattern for each command area. Moreover, the effect of changing the quantities and percentage of salts of surface and ground water on the gross revenue is studied. In addition, the networks of canals and drains are allocated through the simulation model of OPDM. Moreover, the effect of reducing the cultivated rice area on the gross revenue is highlighted.

\section{Model description}

A few attempts have been made to develop irrigation system management or decision support systems to assist water managers in taking appropriate decisions, for example, Command Area Decision Support Model (CADSM) (Prajamwong 1994); Operational and Planning Distribution Model (OPDM) by Utah State University, USA (USU
1996); Operational Management Information System (OMIS) by the Delft Hydraulics, The Netherlands (Delft Hydraulics and DHV Consultants 1989); Irrigation Network Control and Analysis (INCA) by the Overseas Development Unit of HR Wallingford, UK (Makin 1995); Scheme Irrigation Management Information System (SIMIS) by the Water Resources Development and Management Service of FAO's Land and Water Division, Italy (Mateos et al. 2002).

The OPDM (USU 1996) was developed by the department of biological and irrigation Engineering, Utah state university to be used in the planning for water resources and training. It can also be applied in design and analysis studies of agricultural irrigation systems. The model was developed to perform simulation of water distribution and crop yield response for irrigation and other uses in complex canal and drainage networks. Crop water requirements are calculated based on specified cropping patterns and weather information and simulated flows are routed through the systems from main supply sources and open drains. The model is highly interactive with powerful capabilities for system layout and configuration the canal and drainage networks that are built interactively by inserting and arranging nodes graphically.

Operational planning distribution model can generate system flow requirements based on calculated crop water needs specified hydrographically. Daily water balance calculations are preformed for soil water and canal reach storage in the supply and drainage system. The model can estimate relative crop yield reduction due to root zone water deficit, soil water salinity, and water logging. Crop yield results are also used to generate tables of expected gross revenue from crop product based on specified maximum production values. The OPDM calculates crop water requirements by one of five ET methods according to the user's choice. Up to three separate planting staggers of each crop can be specified for each command area. Each crop type can have up to five growth stages with different crop coefficients, root depths, durations, and yield factors. The model used nodes in the system layout to represent specified physical feature that occurs in a real irrigation and drainage system (Fig. 1). The connection between selected node types become reaches that can have capacity and flow data and that are managed on a daily basis by the model during a simulation. The model is used primarily for planning and training activities, but it can also be applied to design and analysis studies of agricultural irrigation systems.

\section{Case study}

The area of the case study is located at Sharkia governorate, Egypt. The project area locates at latitude $32.5^{\circ} \mathrm{N}$ and $30^{\circ}$ longitudinal at an elevation of $10 \mathrm{~m}$ above the 


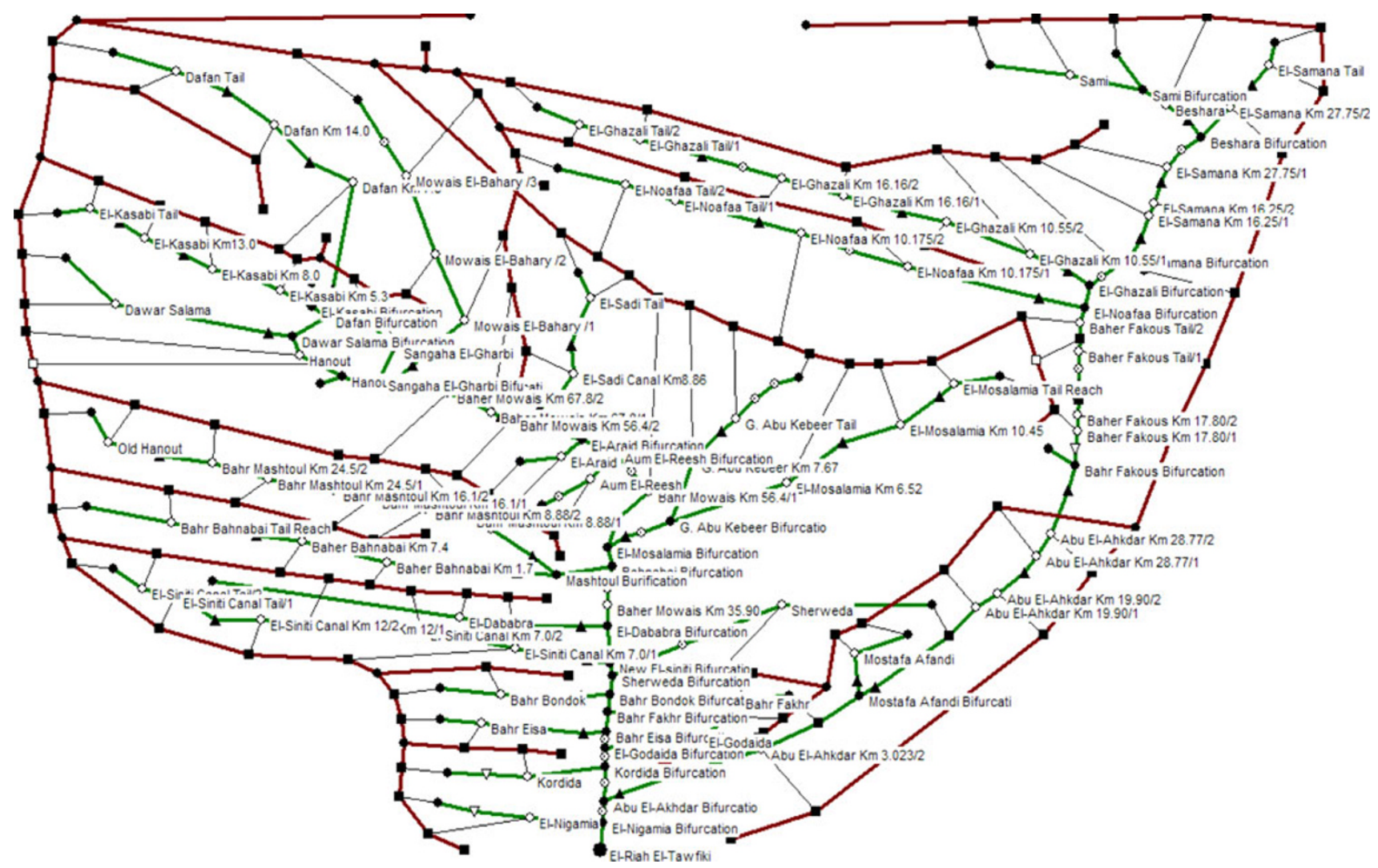

Fig. 1 Sketch of canals and drains networks in Sharkia governorate

mean sea level. The area is irrigated through a network of irrigation canals, and excess water is drained through a network of open drains (Fig. 1). Some water is pumped from an aquifer and used for irrigation along with the surface water. The basic data of the project area that includes the canals and drains networks and all commend areas are shown in Fig. 1. The information of the delivered water to the command areas as a base case is shown in Table 2. This base case is used in comparison with other simulation models of OPDM.

\section{Scenarios studied using OPDM model}

For all commend areas in the case study, different scenarios are considered based on the prospect of water shortage that may be occurred in the future. These scenarios, used by the simulation model of OPDM, include changes in discharge and salinity of both surface water and groundwater. Table 3 shows different scenarios studied by OPDM simulation model. These scenarios include (a) decreasing the amount of surface water or groundwater delivered to the whole command areas, Scenarios (1) and (3) and (b) increasing the salinity of surface water or groundwater, Scenarios (2) and (4).
Table 2 Water resources quantity and quality for the base case

\begin{tabular}{lc}
\hline Surface water discharge $\left(\mathrm{m}^{3} / \mathrm{s}\right)$ & 138.89 \\
Salinity of surface water $(\mathrm{ds} / \mathrm{m})$ & 0.85 \\
Ground water discharge $\left(\right.$ million $\mathrm{m}^{3} /$ year $)\left(\mathrm{m}^{3} / \mathrm{month}\right)$ & 500 \\
Salinity of groundwater $(\mathrm{ds} / \mathrm{m})$ & 0.85 \\
\hline
\end{tabular}

These scenarios covered a wide range of changes in both surface water and groundwater quantities and qualities. The decrease in surface and groundwater quantities ranges from 3 to $30 \%$ with $3 \%$ increment. While, the increase, in surface water and groundwater salinity, ranges from 3 to $30 \%$ with 3\% increment between groups. The results of all groups, by the OPDM model, are studied to investigate the effect of these changes on the gross revenue of the project area.

\section{Analysis of the results}

All scenarios in Table 3 were treated by the OPDM model. It was found the gross revenue decreases as the surface water and groundwater discharges decrease (Figs. 2 and 3). From the previous two figures, the discharges for both surface water and groundwater were reduced relative to the 
Table 3 Different scenarios studied by OPDM

\begin{tabular}{lllll}
\hline Scenario no. & $\begin{array}{l}\text { Surface } \\
\text { water }\left(\mathrm{m}^{3} / \mathrm{s}\right)\end{array}$ & $\begin{array}{l}\text { Salinity of } \\
\text { surface water }(\mathrm{ds} / \mathrm{m})\end{array}$ & $\begin{array}{l}\text { Groundwater } \\
\left(\mathrm{m}^{3} / \mathrm{year}\right)\end{array}$ & $\begin{array}{l}\text { Salinity of ground } \\
\text { water }(\mathrm{ds} / \mathrm{m})\end{array}$ \\
\hline 1 & $\begin{array}{c}\text { Decrease by } 3 \% \\
\text { for } 10 \text { times }\end{array}$ & 0.85 & $500,000,000$ & 0.85 \\
2 & 138.89 & $\begin{array}{c}\text { Increase by } \\
3 \% \text { for } 10 \text { times }\end{array}$ & $\begin{array}{l}500,000,000 \\
\text { Decrease by } 3 \% \\
\text { for } 10 \text { times }\end{array}$ & 0.85 \\
3 & 138.89 & 0.85 & $500,000,000$ & $\begin{array}{c}\text { Increase by } 3 \% \\
\text { for } 10 \text { times }\end{array}$ \\
\hline
\end{tabular}

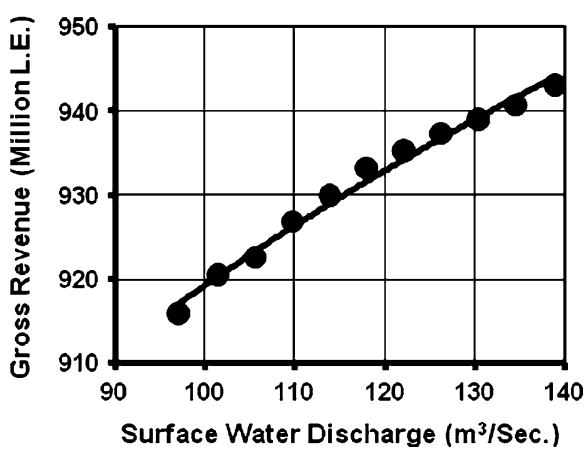

Fig. 2 Simulation of gross revenue related to the different surface water discharges for the project area

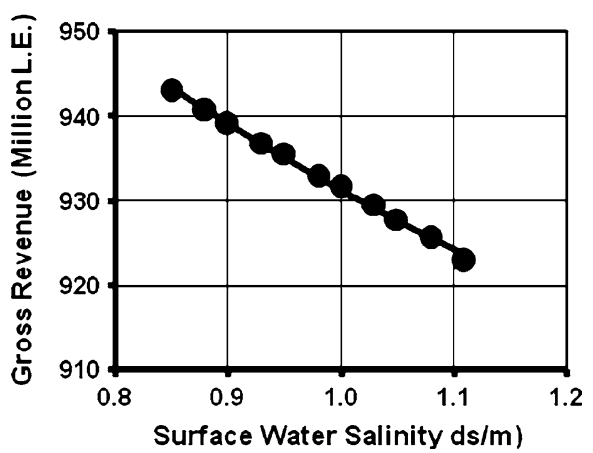

Fig. 3 Simulation of gross revenue related to the different surface water salinities for the project area

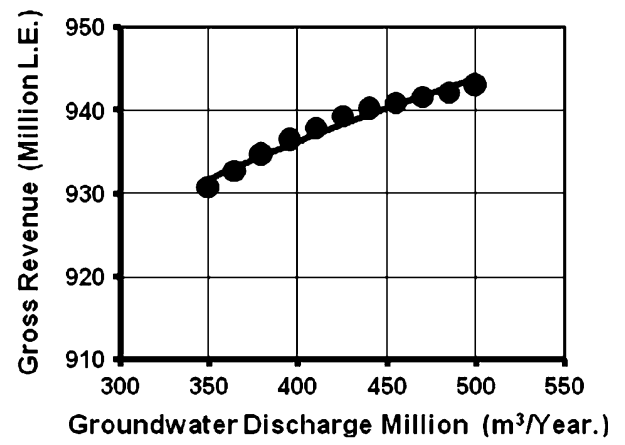

Fig. 4 Simulation of gross revenue related to the different groundwater discharges for the project area

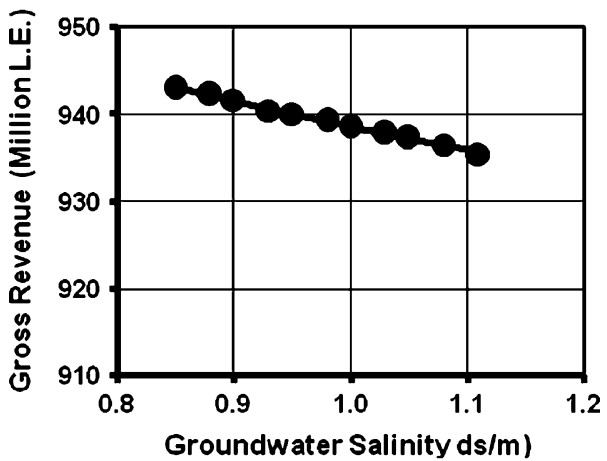

Fig. 5 Simulation of gross revenue related to the different groundwater salinities for the project area

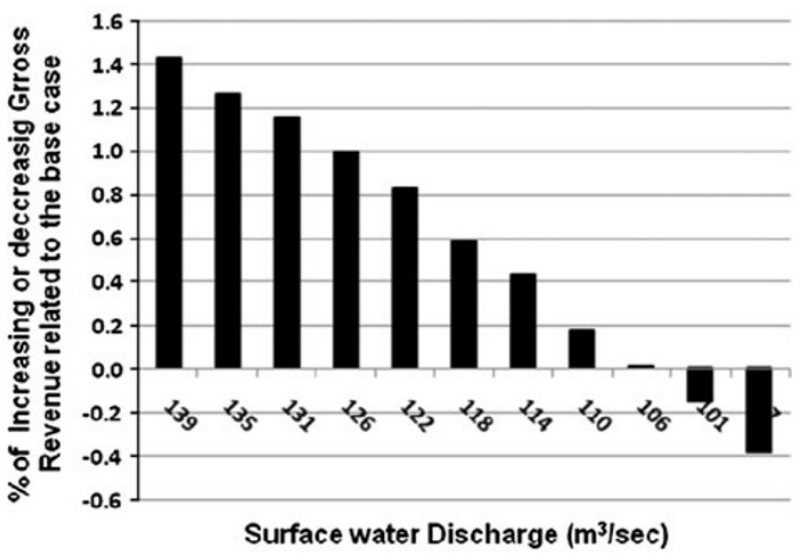

Fig. 6 Results of OPDM simulation model for $60 \%$ area grown by rice

base case, as it probably occurred in the future. In the contrary, the gross revenue decreases as the surface water and groundwater salinities increase (Figs. 3 and 5). In which, the increase in water salinity above certain values affects the yield of crops.

From Figs. 2 and 4, it was found that the effect of reducing surface water quantities on the gross revenue is 
larger than the effect of reducing the groundwater quantities through the simulation model.

Another interesting example that offers insights into processes of water resource management in Egypt are the recent attempts to shift cropping patterns toward less water-consuming crops. That can be done by controlling the area grown by some crops such as rice. In the present study, different scenarios were carried out using OPDM model including decreasing the rice area by $40 \%$. In which, the decreased area from rice is replaced by cotton and maize. These scenarios were correlated to different surface water discharges as shown in Fig. 6. From this figure, It can be noticed that the percentage of gross revenue relative to the base case increases for almost surface water discharges. That means by decreasing the rice area by $40 \%$ in Sharkia governorate and replaced it by another crops like cotton and maize, the gross revenue will increase slightly with smaller amount of surface water discharge compared to the base case.

\section{Conclusions}

The government of Egypt affords great role to the management of water resources especially with expanding the cultivated areas to meet the increasing growth of population. Accordingly, the supplies of Nile River to the Nile Delta will be negatively affected. In the present study, the OPDM is implemented on Sharkia governorate to show the effect of water resource management on the gross revenue. The gross revenue of all command areas is correlated to surface water discharge, ground water discharge, surface water salinity, and ground water salinity. It is cleary found that the gross revenue decreases as the surface water and groundwater discharges decrease. The effect of reducing surface water quantities on the gross revenue is larger than the effect of reducing the groundwater quantity in simulation model. In addition, the gross revenue decreases as the surface water and groundwater salinities increase. Scenarios for reducing the grown rice area were carried out. By replacing $40 \%$ of rice area by cotton and maize, the gross revenue for all command areas could be slightly increased with lower supplies of surface water discharges relative to the base case. So, other scenarios for new studies should be carried out to clarify the economic and social effects due to change crop patterns on Sharkia governorate.
Open Access This article is distributed under the terms of the Creative Commons Attribution License which permits any use, distribution and reproduction in any medium, provided the original author(s) and source are credited.

\section{References}

Allam MN, Allam GI (2007) Water resources in Egypt: future challenges and opportunities. Int Water Resour Assoc Water Int 32(2):205-218

Bou-Zied E, El-Fadel M (2002) Climate change and water resources in Lebanon and the middle east. J Water Res Plan Manage 128:343-355

Cecilia F, Rob C, Reid D (2008) Imagined communities, contested watersheds: challenges to integrated water resources management in agricultural areas. J Rural Stud 24:304-321

Delft Hydraulics, DHV Consultants BV (1989) Cidurian upgrading and water management project: OMIS-notes on modelling concepts. User's Manual, Jakarta

Dennis W (1999) Economic efficiency and irrigation water $r$ policy with an example from Egypt. Water Resour Dev 15(4):543-560

Elarabawy M, Tosswell P, Attia B (2000) Integrated water resources management for Egypt. J Water Serv Res Technol AQUA 49(3):111-125

El-Sadek A (2010) Water desalination: an imperative measure for water security in Egypt. Desalination 250:876-884

El-Sadek A, El Kahloun M, Meire P (2008) Ecohydrology for integrated water resources management in the Nile Basin. Ecohydrol Hydrobiol 8(2-4):237-244

Kenneth MS, David N, El Quosy DED (1996) Vulnerability assessment of water resources in Egypt to climatic change in the Nile Basin. Clim Res 6:89-95

Luzi L (2010) Driving forces and patterns of water policy making in Egypt. Water Policy 12:92-113

Makin IW (1995) INCA: irrigation management software. In: Information technologies for irrigation systems. Network Newsletter. Int Irrig Mgmt Inst (IIMI) 2(1):22-24

Mateos L, López-Cortijo I, Sagardoy JA (2002) The FAO decision support system for irrigation scheme management. Agric Water Manag 56:193-206

MWRI and USAID (2002) Inter-ministerial water policy integration. Ministry of Water Resources and Irrigation, Cairo

MWRI and World Bank (2003) Holistic approach to water resources management, stock-taking of IWRM in Egypt: policy and practice. Ministry of Water Resources and Irrigation, Cairo

Prajamwong S (1994) Command area decision support system for irrigation projects. PhD Dissertation, Department of Biology and Irrigation Engineering, Utah State University, Logan, UT

USU (1996) Operation and planning distribution model (OPDM). Soft User's Guide, Ver. 2.02, Department of Biology and Irrigation Engineering, Utah State University (USU), Logan, UT 